\title{
How Related are Interbank and Lending Interest Rates? Evidence on Selected European Union Countries ${ }^{\#}$
}

\author{
Tomáš HERYÁN* - Daniel STAVÁREK **
}

\section{Introduction}

Interest rates on loans are crucial in terms of profitability of banks. Particularly in times affected by the financial crisis they should be given a considerable degree of attention. From the profit's point of view we should see interest rates in two ways. First, we can distinguish a positive impact on operating results of commercial banks. Second, lending interest rate influence costs of borrowers and can be destructive for many companies today.

This article aims to trace the relationship between interbank market interest rates and interest rates on loans for business companies. The paper also investigates development of banks' profit margin during the financial crisis. The development is demonstrated in selected euro area countries (Austria, Belgium, France and Italy) that are home countries of owners of the largest banks that dominate the Czech banking sector (Česká spořitelna, Československá obchodní banka, Komerční banka and UniCredit Bank).

The paper is divided into several sections. The introduction is followed by a brief overview of recent relevant scientific findings. Next the characteristics of data and methods used in the paper are presented.

\# Research behind this paper was supported by the Student Grant Competition of Silesian University within the project SGS 25/2010 Financial integration in the EU and its effect on corporate sector.

* Ing. Tomáš Heryán - internal Ph.D. student; Department of Finance at Silesian University, School of Business Administration in Karvina, Univerzitní náměstí 1934/3, 733 40, Karviná, Czech Republic; <heryan@opf.slu.cz>.

** Doc. Ing. Daniel Stavárek, Ph.D. - Associate Professor; Department of Finance at Silesian University, School of Business Administration in Karvina, Univerzitní náměstí 1934/3, 733 40, Karviná, Czech Republic; <stavarek@opf.slu.cz>. 
Then the empirical part follows and, finally, discussion on empirical results along with the conclusion close the paper.

\section{The last recent scientific information overview}

Interest rates in converging economies are more unstable than in the euro area, hence interest rate risk in these countries is likely to be significantly elevated during periods of financial markets distress (Orlowski, 2010). Another problem is that national real interest rates can differ from the euro area average for considerable periods. The loss of monetary independence may imply differential transmission dynamics towards a common steady-state. This may result in sub-optimal economic stabilization and other costs, as the welfare implications of ultimately transitory yet persistent real interest rate differentials are unknown but significant (Arghyrou et al., 2009).

We should also discuss the role of monetary policy and its interest rates, even though the impacts of policy measures may be different during financial crises. Orlowski (2010) shows that changes in the euro area short-term interest rates strongly drive adjustments in the central banks' reference interest rates. Gerlach and Rudolf argue that monetary policy is typically formulated with a very short-term interest rate, while longer rates matter in the transmission mechanism. They show that financial market shocks impact less on the macroeconomy if policy is set with a longer rate. The financial crisis of 2007/08 according their opinion has shown that the market interest rate used the central bank to formulate monetary policy displays comparatively little variation in response to financial shocks (Gerlach - Rudolf, 2010).

Kasman et al. examine bank net interest margins in EU member countries. They use also bank-level data for all EU countries in the sample were obtained from the Bank-Scope database for period 1996 2006 (Kasman et al., 2010). It is logical that we cannot use bank-level data for period affected by financial crises to examine development of bank gross margins (it means credit profitability, render down), for the present (April 2010). Since prices and marginal costs may be affected differently by technical change, interest rates, the business cycle and other macroeconomic influences (Valverde - Fernandez, 2007), we interested in only on credit profit margin, as spread between lending rate and interbank offer rate. 


\section{Data and methodology}

We use EURIBOR and PRIBOR as interest rate of the euro area and the Czech Republic interbank market respectively. The lending rate is defined as the interest rate of loans granted in three maturity categories of each country (short maturity $<1$ year, medium maturity $1-5$ years, and long maturity $>5$ years). All data are used in a monthly frequency and cover the period from January 2004 to March 2010. All the data are taken from the European Central Bank and Czech National Bank online databases. Methods our used in this article are based on statistical testing. The empirical methods applied in the paper are standard and has been widely used in literature. Therefore, we do not provide a detail description of the methodology. The long-term interactions between the interest rates are examined using Johansen Cointegration Test. Next, the short-term interactions are analyzed using Granger Causality Test. All the empirical testing is processed in EViews 7 software package.

The majority owners companies of the Czech largest banks that dominate the Czech banking sector are presented in Table 1. The market shares are measured on total assets of the Czech banking sector as of August 2010. The numbers reported clearly show that the Czech banking sector is highly concentrated as more than $60 \%$ of the banking sector's assets are held by four largest banks.

Tab. 1: Concentration and ownership of the Czech banking sector

\begin{tabular}{|l|r|l|}
\hline & \multicolumn{1}{|c|}{ Market } & \multicolumn{1}{|c|}{ Majority owner } \\
\hline ČSOB & $19.76 \%$ & KBC group, N.V. \\
\hline Česká spořitelna & $19.67 \%$ & Erste Group Bank, \\
\hline Komerční banka & $15.99 \%$ & Société Générale, S.A. \\
\hline Unicredit bank & $6.09 \%$ & Unicredit, S.p.A. \\
\hline Total & $\mathbf{6 1 . 5 0 \%}$ & \\
\hline
\end{tabular}

Source: Authors calculation from the Czech National Bank Online Database. 


\section{Empirical results}

\subsection{Test for Stationarity and Cointegration Analysis}

The first step in empirical analysis is testing for stationarity of the time series used. For this purpose, we applied the Augmented Dickey-Fuller Test (ADF). The results are reported in Table 2. When we made the first step, unit roots (using ADF tests on first difference level, intercept include in test equation), now we can make the Johansen System Cointegration Test.

We choose Intercept (no trend) in CE - no intercept in VAR, and choose 12 lags show long-runs between interest rates of loans and interbank interest rates (Table 3). Trace test together with Maxeigenvalue test indicates most often one cointegrating eqn(s) at the 5\% level (at rejection of the hypothesis) with one and twelve lags.

Tab. 2: Unit root tests for loans and interbank interest rates

\begin{tabular}{|l|c|c|c|c|c|c|}
\hline \multirow{2}{*}{$\begin{array}{c}\text { Loans interest } \\
\text { rate }\end{array}$} & \multicolumn{2}{|c|}{$\begin{array}{c}\text { Loan maturity } \\
<\mathbf{1} \text { year }\end{array}$} & \multicolumn{2}{c|}{$\begin{array}{c}\text { Loan maturity } \\
\mathbf{1}<\mathbf{5} \text { years }\end{array}$} & \multicolumn{2}{c|}{$\begin{array}{c}\text { Loan maturity } \\
>\mathbf{5} \text { years }\end{array}$} \\
\cline { 2 - 7 } & level & $\mathbf{1}^{\text {st }}$ dif. & level & $\mathbf{1}^{\text {st }}$ dif. & level & $\boldsymbol{1}^{\text {st }}$ dif. \\
\hline Austria & -1.93 & $-5.23^{*}$ & -1.91 & $-2.56^{* *}$ & -2.17 & $-2.06^{* *}$ \\
\hline Belgium & -0.81 & $-6.03^{*}$ & -0.84 & - & -0.71 & $-3.80^{*}$ \\
\hline Czech Republic & -1.61 & $-10.17^{*}$ & -2.12 & $-10.12^{*}$ & -2.19 & $-13.33^{*}$ \\
\hline France & -0.50 & $-5.98^{*}$ & -0.09 & $-6.88^{*}$ & 0.75 & $-10.73^{*}$ \\
\hline Italy & -1.26 & $-3.58^{*}$ & -1.65 & $-2.71^{*}$ & -2.00 & $-2.65^{*}$ \\
\hline
\end{tabular}

\begin{tabular}{|l|c|c|c|c|c|c|c|c|}
\hline \multirow{2}{*}{$\begin{array}{l}\text { Interbank } \\
\text { interest rate }\end{array}$} & \multicolumn{2}{|c|}{$\mathbf{1}$ month } & \multicolumn{2}{c|}{$\mathbf{3}$ months } & \multicolumn{2}{c|}{$\mathbf{6}$ months } & \multicolumn{2}{c|}{ 12 months } \\
\cline { 2 - 9 } & level & $\mathbf{1}^{\text {st }}$ dif. & level & $\mathbf{1}^{\text {st }}$ dif. & level & $\mathbf{1}^{\text {st }}$ dif. & level & $\mathbf{1}^{\text {st }}$ dif. \\
\hline EURIBOR & -0.85 & $-4.86^{*}$ & -1.42 & $-3.45^{*}$ & -1.69 & $-3.20^{*}$ & -1.76 & $-3.28^{*}$ \\
\hline PRIBOR & -1.12 & $-5.50^{*}$ & -0.98 & $-5.28^{*}$ & -1.44 & $-5.75^{*}$ & -1.53 & $-5.86^{*}$ \\
\hline
\end{tabular}

Source: Authors calculation.

Legends: * and ** means significance on 1 and $5 \%$ level. 


\subsection{Granger Causality Test}

The Granger Causality Test approaches to the question of whether growth of the interbank interest rate causes growth of business loans lending interest rate. There is to see how much of the current change of growth of lending interest rate can be explained by past values of them and then to see whether adding lagged values of growth of interbank interest rate can improve the explanation. Change of corporate lending interest rate is said to be Granger-caused by change of interbank interest rate if change of interbank interest rate helps in the prediction of change of lending interest rate, or equivalently if the coefficients on the lagged change of interbank interest rates are statistically significant. Note that two-way causation is frequently the case: change of interbank interest rate Granger causes change of lending interest rate and change of lending interest rate Granger causes change of interbank interest rate.

It is important to note that the statement for example 'growth of interbank interest rate Granger causes growth of lending interest rate' does not imply that growth of lending interest rate is the effect or the result of growth of interbank interest rate. Granger causality measures precedence and information content but does not by itself indicate causality in the more common use of the term.

The null hypothesis is that change of interbank interest rate does not Granger-cause change of interest rate loans granted in the first regression and that change of loans interest rate does not Granger-cause change of interbank interest rate in the second regression (in rate of growth of course). For our example, we cannot reject the hypothesis that growth of lending interest rate does not Granger-cause growth of interbank interest rate but we do reject the hypothesis that growth of interbank interest rate does not Granger-cause growth of lending interest rate. Therefore it appears that Granger causality runs one-way from growth of interbank interest rates to growth of corporate lending interest rates in all our selected countries and not the other way (Table 4). ${ }^{1}$

\footnotetext{
${ }^{1}$ Theoretical basics of our used empirical methods are described in e.g. Econometrics Theory and Applications with EViews, Vogelvang (2005), or in EViews User Guides.
} 


\section{Tab. 1: Johansen Cointegration Tests}

\begin{tabular}{|c|c|c|c|c|c|c|c|c|c|c|c|c|c|c|}
\hline c & $T$ & Long-run relationship & $\alpha$ & \multirow{4}{*}{ NOME } & c & T & Long-run relationship & & \multirow{4}{*}{ NOME } & c & $T$ & Long-run relationship & & \\
\hline \multirow{3}{*}{ 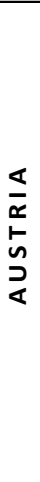 } & 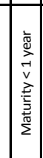 & 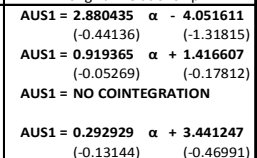 & $\begin{array}{l}\text { EURIBOR 1m } \\
\text { EURIBOR 3m } \\
\text { EURIBOR 6m } \\
\text { EURIBOR 12m }\end{array}$ & & \multirow{3}{*}{$\begin{array}{l}\sum \\
\vdots \\
\\
\\
\infty\end{array}$} & 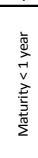 & $\begin{array}{ccc}\text { BEL1 }=0.844793 & \alpha+1.959344 \\
(-0.06408) & (-0.19653) \\
\text { BEL1 } & 0.755732 & \alpha+2.077796 \\
(-0.05479) & (-0.181212) \\
\text { BEL1 }=0.758705 & \alpha+1.975985 \\
(-0.06502) & (-0.22381) \\
\text { BEL1 }=0.737326 & \alpha+1.9255274 \\
(-0.0762) & (-0.27224)\end{array}$ & $\begin{array}{l}\text { EURIBOR 1m } \\
\text { EURIBOR 3m } \\
\text { EURIBOR 6m } \\
\text { EURIBOR 12m }\end{array}$ & & \multirow{3}{*}{ 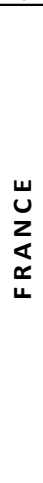 } & 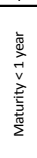 & 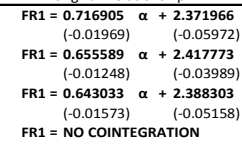 & $\begin{array}{l}\text { EURIBOR 1m } \\
\text { EURIBOR 3m } \\
\text { EURIBOR 6m } \\
\text { EURIBOR 12m }\end{array}$ & \\
\hline & 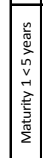 & 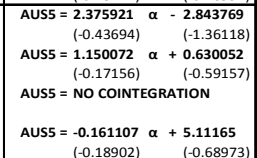 & $\begin{array}{l}\text { EURIBOR 1m } \\
\text { EURIBOR 3m } \\
\text { EURIBOR 6m } \\
\text { EURIBOR 12m }\end{array}$ & & & 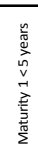 & $\begin{array}{l}\text { BEL5 = NO COINTEGRATION } \\
\text { BEL5 = NO COINTEGRATION } \\
\text { BELL = NO COINTEGRATION } \\
\text { BEL5 = NO COINTEGRATION }\end{array}$ & $\begin{array}{l}\text { EURIBOR 1m } \\
\text { EURIBOR 3m } \\
\text { EURIBOR 6m } \\
\text { EURIBOR 12m }\end{array}$ & & & 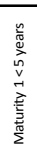 & $\begin{array}{l}\text { FR5 }=\text { NO COINTEGRATION } \\
\text { FR5 }=\text { NO COINTEGRATION } \\
\text { FR5 }=\text { NO COINTEGRATION } \\
\text { FR5 }=\begin{array}{ll}1.565243 & \alpha-0.767998 \\
(-0.30841) & (-1.07561)\end{array}\end{array}$ & $\begin{array}{l}\text { EURIBOR 1m } \\
\text { EURIBOR 3m } \\
\text { EURIBOR 6m } \\
\text { EURIBOR 12m }\end{array}$ & \\
\hline & 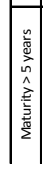 & 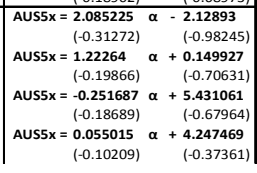 & $\begin{array}{l}\text { EURIBOR 1m } \\
\text { EURIBOR 3m } \\
\text { EURIBOR 6m } \\
\text { EURIBOR 12m }\end{array}$ & & & 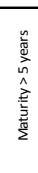 & 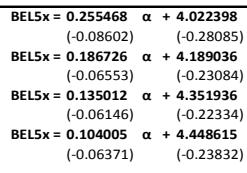 & $\begin{array}{l}\text { EURIBOR 1m } \\
\text { EURIBOR 3m } \\
\text { EURIBOR 6m } \\
\text { EURIBOR 12m }\end{array}$ & & & 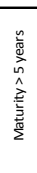 & 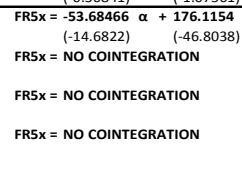 & $\begin{array}{l}\text { EURIBOR 1m } \\
\text { EURIBOR 3m } \\
\text { EURIBOR 6m } \\
\text { EURIBOR 12m }\end{array}$ & \\
\hline c & $|T|$ & Long-run relationship & $\alpha$ & & c & $T$ & Long-run relationship & $\alpha$ & & c & T & Long-run relationship & $\alpha$ & \multirow{3}{*}{$\begin{array}{l}\text { NOTS } \\
\text { - NOME } \\
\text { NOME } \\
\text { NOME }\end{array}$} \\
\hline \multirow{3}{*}{$\begin{array}{l}\searrow \\
\varangle \\
上\end{array}$} & 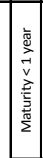 & 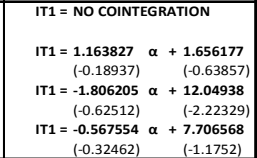 & $\begin{array}{l}\text { EURIBOR 1m } \\
\text { EURIBOR 3m } \\
\text { EURIBOR } 6 \mathrm{~m} \\
\text { EURIBOR 12m }\end{array}$ & $2 T S \& 2 M E$ & $\underline{-}$ & 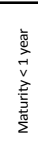 & 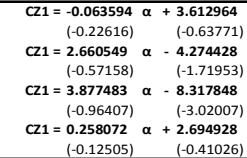 & $\begin{array}{l}\text { EURIBOR 1m } \\
\text { EURIBOR 3m } \\
\text { EURIBOR 6m } \\
\text { EURIBOR 12m }\end{array}$ & $2 T S \& 2 M E$ & $\underline{\underline{u}}$ & 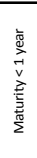 & 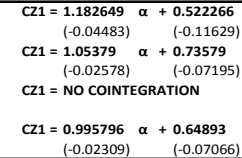 & $\begin{array}{l}\text { PRIBOR 1m } \\
\text { PRIBOR 3m } \\
\text { PRIBOR 6m } \\
\text { PRIBOR 12m }\end{array}$ & \\
\hline & 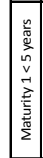 & 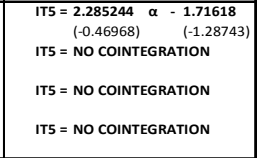 & $\begin{array}{l}\text { EURIBOR 1m } \\
\text { EURIBOR 3m } \\
\text { EURIBOR } 6 \mathrm{~m} \\
\text { EURIBOR 12m }\end{array}$ & & $\begin{array}{l}\infty \\
D \\
a \\
\omega \\
\sim\end{array}$ & 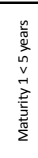 & 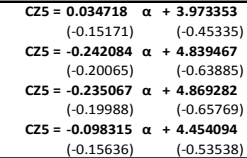 & $\begin{array}{l}\text { EURIBOR 1m } \\
\text { EURIBOR 3m } \\
\text { EURIBOR 6m } \\
\text { EURIBOR 12m }\end{array}$ & & 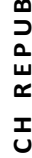 & 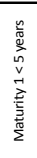 & $\begin{array}{l}\text { CZ5 = NO COINTEGRATION } \\
\text { C25 = NO COINTEGRATION } \\
\text { C25 = NO COINTEGRATION } \\
\text { C25 = NO COINTEGRATION }\end{array}$ & $\begin{array}{l}\text { PRIBOR 1m } \\
\text { PRIBOR 3m } \\
\text { PRIBOR 6m } \\
\text { PRIBOR 12m }\end{array}$ & \\
\hline & 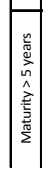 & 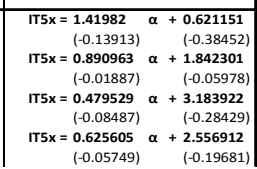 & $\begin{array}{l}\text { EURIBOR 1m } \\
\text { EURIBOR 3m } \\
\text { EURIBOR 6m } \\
\text { EURIBOR 12m }\end{array}$ & $2 T S \& 2 M E$ & $\stackrel{\Psi}{N}$ & 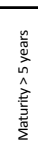 & $\begin{array}{l}\text { CZ5 } x=\text { NO COINTEGRATION } \\
\text { CZ5 }=\text { NO COINTEGRATION } \\
\text { C25 } x=\text { NO COINTEGRATION } \\
\text { CZ5 } x=\text { NO COINTEGRATION }\end{array}$ & $\begin{array}{l}\text { EURIBOR 1m } \\
\text { EURIBOR 3m } \\
\text { EURIBOR 6m } \\
\text { EURIBOR 12m }\end{array}$ & $\begin{array}{l}\text { 2TS NOME } \\
\text { 2TS NOME } \\
\text { 2TS NOME } \\
\text { NOME }\end{array}$ & $\stackrel{w}{N}$ & 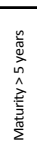 & 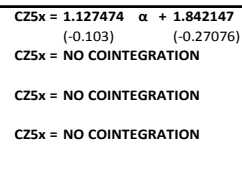 & $\begin{array}{l}\text { PRIBOR 1m } \\
\text { PRIBOR 3m } \\
\text { PRIBOR 6m } \\
\text { PRIBOR 12m }\end{array}$ & \\
\hline
\end{tabular}

Explanatory: $C$ means country, $T$ means type of interest rate loans (dependent variable), $\alpha$ is interbank rate (explanatory variable), $T S$ means Trace test, $M E$ means Max-eigenvalue test.

Source: Authors calculation. 


\section{Table 2: Pairwise Granger Causality Tests (2 Lags)}

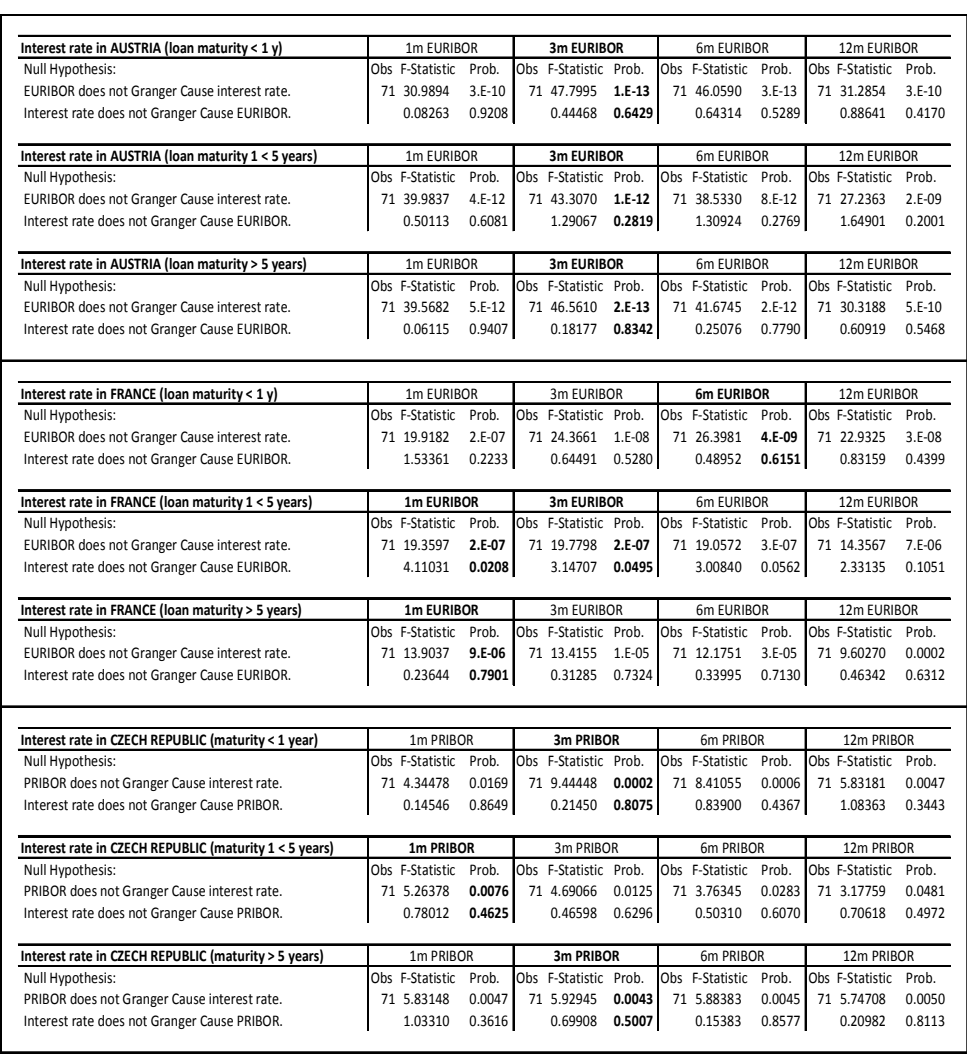

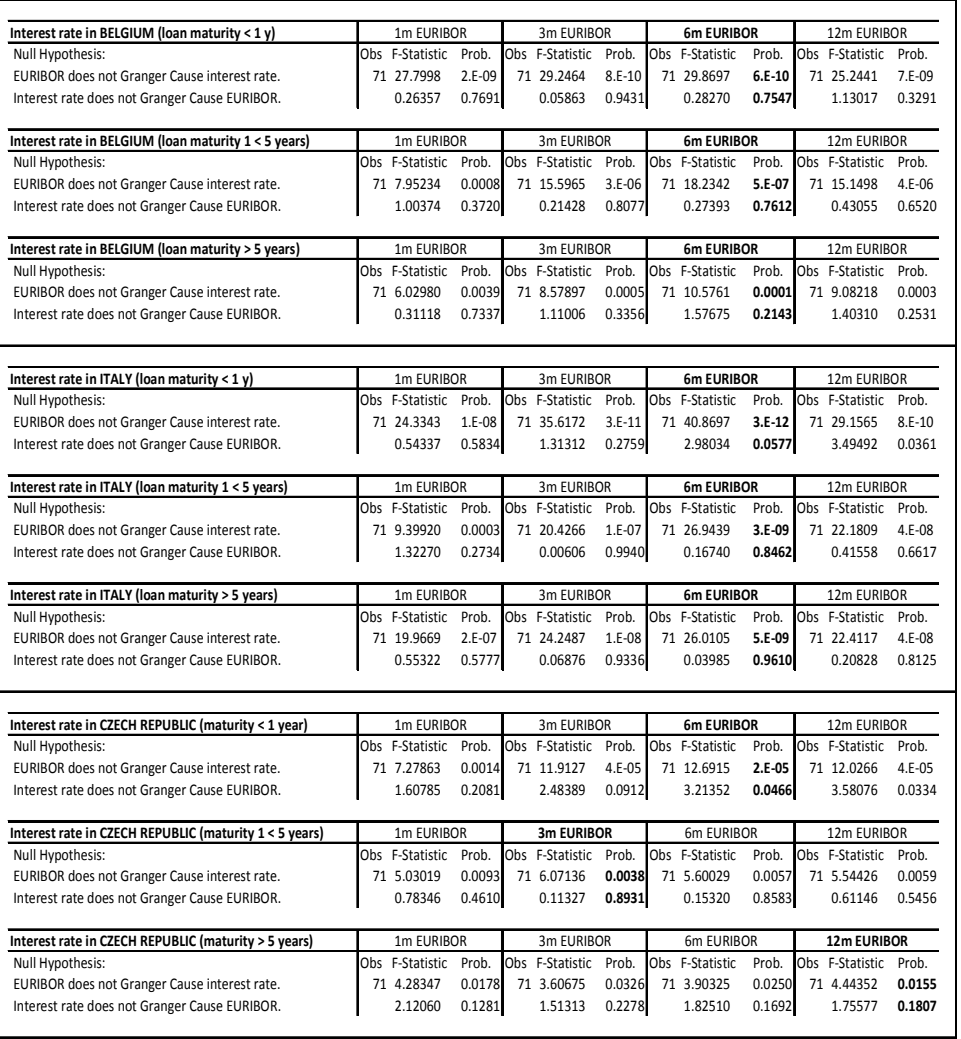

Note: The most significant relationships between interbank rates and interest rates of corporate loans are highlighted in bold. Source: Authors calculation. 


\section{Discussion on empirical results}

As we can see, both long-run and short-run causalities between interbank interest rates and interest rates on corporate loans do really exist. Johansen Cointegration Tests show us that long-run interactions does not exist between all categories of interest rates, but short-run interactions with Granger Causalities are proven between all.

Graphs in Appendix 1 depict the development of actual interest rates in the selected countries. During the time when the financial crisis is reflected in full, interbank rates decreased very quickly and then they are at low levels. It is caused by lower supply and demand and greater degree of risk in the money market. The development of lending interest rates differs across the maturity categories as well as countries. The Czech Republic is described twice in graphs, because we use two interbank rates. Obviously, we use the Czech PRIBOR but EURIBOR is also used as the reference interest rate for lending in the Czech Republic. Due to the categorization system used, the lending interest rate is sometimes lower than the interbank interest rate. It can be explained by the fact that this situation exists because in our three lending rate categories, there are less foreign currency loans.

Graphs in Appendix 2 depict the development of credit profit margins of banks. We define the credit margin like a difference between the interest rate on corporate loans of each category according to the loan maturity and the interbank interest rate respective for each country. In the case of the Czech Republic, we only report the credit margin calculated using PRIBOR rates. The paper suffers from unavailability of information on the total amount of loans granted in individual maturity categories in some countries. Hence, we are not able to recognize how important is each maturity category for the lending operations of banks and what's the contribution of each category to the total profit margin. Nevertheless, one can see that all three measures of credit margins rise up during the period affected by financial crisis. Banks follow this way to avoid losses arising from providing bad (non-performing) loans.

It is impossible to report cash flows between the parent banks and their subsidiaries but correlations between interbank and loan interest rates show some interesting insights. Table in Appendix 3 contains the correlation coefficients between changes in the interbank interest rates and changes in the bank profit margin. We expect negative coefficients 
because a growth of the interbank interest rate should cause a decrease in the profit margin. Interestingly enough, the correlation coefficients in the Czech Republic are not only much closer to zero than in remaining countries but some coefficients even reach positive values (especially for a combination of lending interest rates and PRIBOR). This demonstrates that the scope for margin payments between subsidiaries and their parent banks could actually exist.

\section{Conclusion}

The aim of the paper was to trace the relationship between interbank market interest rates and interest rates on loans for business companies, and also investigating profit margin of bank's active operations during the financial crisis.

In the first part of this paper we demonstrated long term causalities among some interest rates on corporate loans and interbank interest rates in all our selected countries. Short term causalities between all of interest rates do exist which means that interbank market affect to some extend lending rates also during the financial crises in these countries.

Next part of the paper aimed to demonstrate the opinion that foreign owners of the Czech largest banks could affect development of the Czech credit margin to secure a sufficient margin of the subsidiaries to offset their financial losses. Based on correlation values between interbank interest rates and bank credit margins we only demonstrated that it could be possible. Our results, although of incremental nature, prove that this problem makes sense and should be examined in more details in a forthcoming research. The next step could be the analysis of development of net banking margins using financial data of individual banks (taken e.g. from the BankScope database).

\section{References}

[1] Arghyrou, M. G. - Gregoriou, A. - Kontonikas, A. (2009): Do Real Interest Rates Converge? Evidence from the European Union. Journal of International Financial Markets, Institutions and Money, 2009, vol. 19 , no. 3, pp. 447-460. 
[2] Gerlach, K. P. - Rudolf, B. (2010): Financial Shocks and the Maturity of the Monetary Policy Rate. Economics Letters, 2010, vol. 107, no. 3, pp. 333-337.

[3] Kasman, A. - Tunc, G. - Vardar, G. - Okan, B. (2010): Consolidation and Commercial Bank Net Interest Margins: Evidence from the Old and New European Union Members and Candidate Countries. Economic Modelling, 2010, vol. 27, no. 3, pp. 648-655.

[4] Orlowski, L. T. (2010): Monetary Policy Rules for Convergence to the Euro. Economic Systems, 2010, vol. 34, no. 2, pp. 148-159.

[5] Valverde, S. C. - Fernandez, F. R. (2007): The Determinants of Bank Margins in European Banking. Journal of Banking \& Finance, 2007, vol. 31, no. 7, pp. 2043-2063.

[6] Vogelvang, B. (2005): Econometrics Theory and Applications with EViews. Chapter 12 Dynamic Models, Unit Roots and Cointegration. Harlow, Pearsons Education, 2005. 
Heryán, T. - Stavárek, D.: How Related are Interbank and Lending Interest Rates? Evidence on Selected European Union countries.

\section{Appendix 1: Development of interest rates in the selected euro area countries and in the Czech Republic}
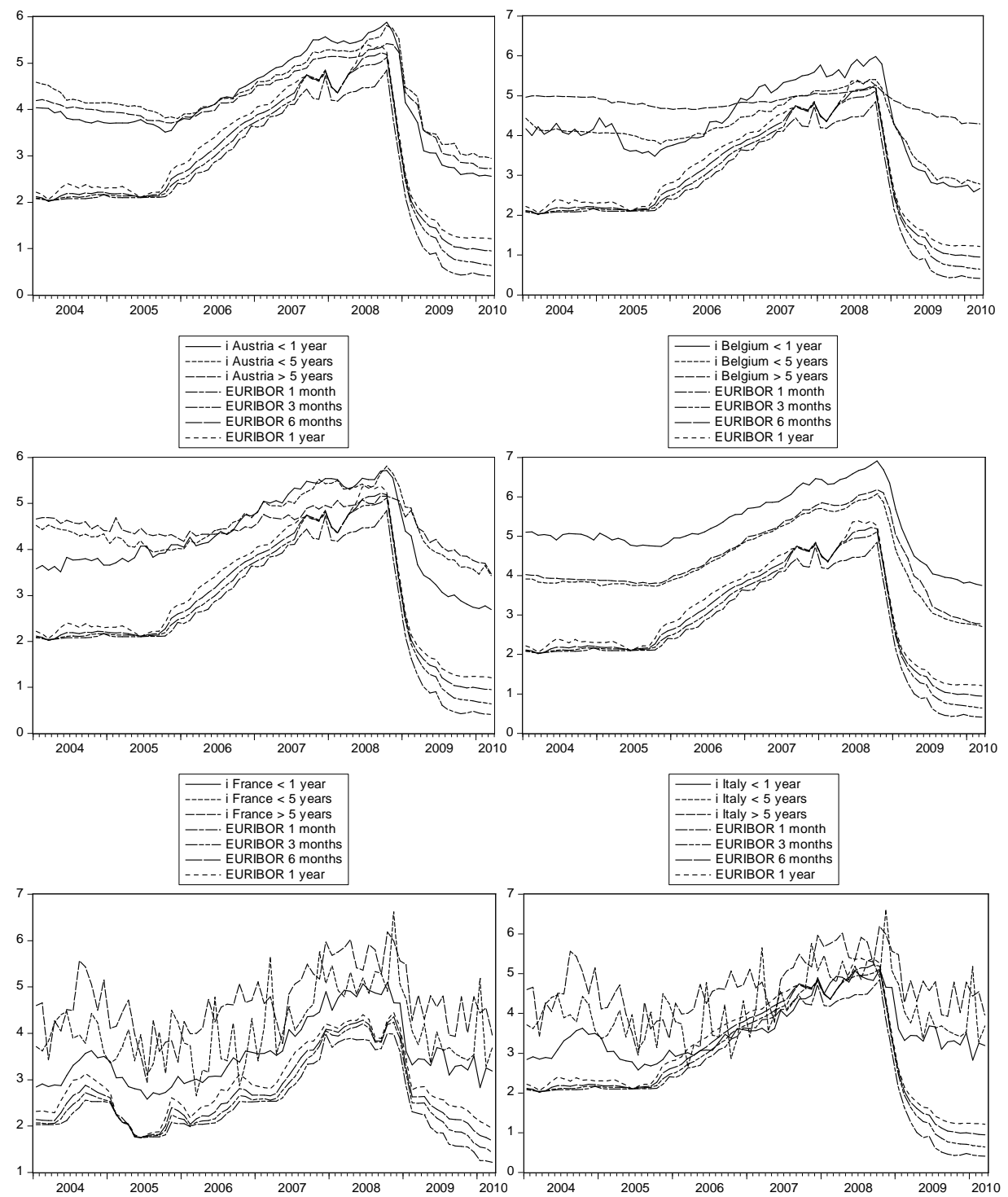

\begin{tabular}{|c|}
\hline $\begin{array}{l}\text { i Czech Republic }<1 \text { year (CNB) } \\
---- \text { i Czech Republic }<5 \text { years (CNB) } \\
---- \text { i Czech Republic }>5 \text { years (CNB) } \\
\text {--_. PRIBOR } 1 \text { month } \\
--- \text { PRIBOR } 3 \text { months } \\
- \text { - PRIBOR } 6 \text { months } \\
--- \text { PRIBOR } 1 \text { year }\end{array}$ \\
\hline
\end{tabular}

\begin{tabular}{|l|}
\hline- i Czech Republic $<1$ year (CNB) \\
----- i Czech Republic $<5$ years (CNB) \\
--- i Czech Republic $>5$ years (CNB) \\
--- EURIBOR 1 month \\
--- EURIBOR 3 months \\
- - EURIBOR 6 months \\
-- . EURIBOR 1 year
\end{tabular}


European Financial and Accounting Journal, 2010, vol. 5, no. 3-4, pp. 42-55.

\section{Appendix 2: Development of credit margin (according to the loan maturity)}
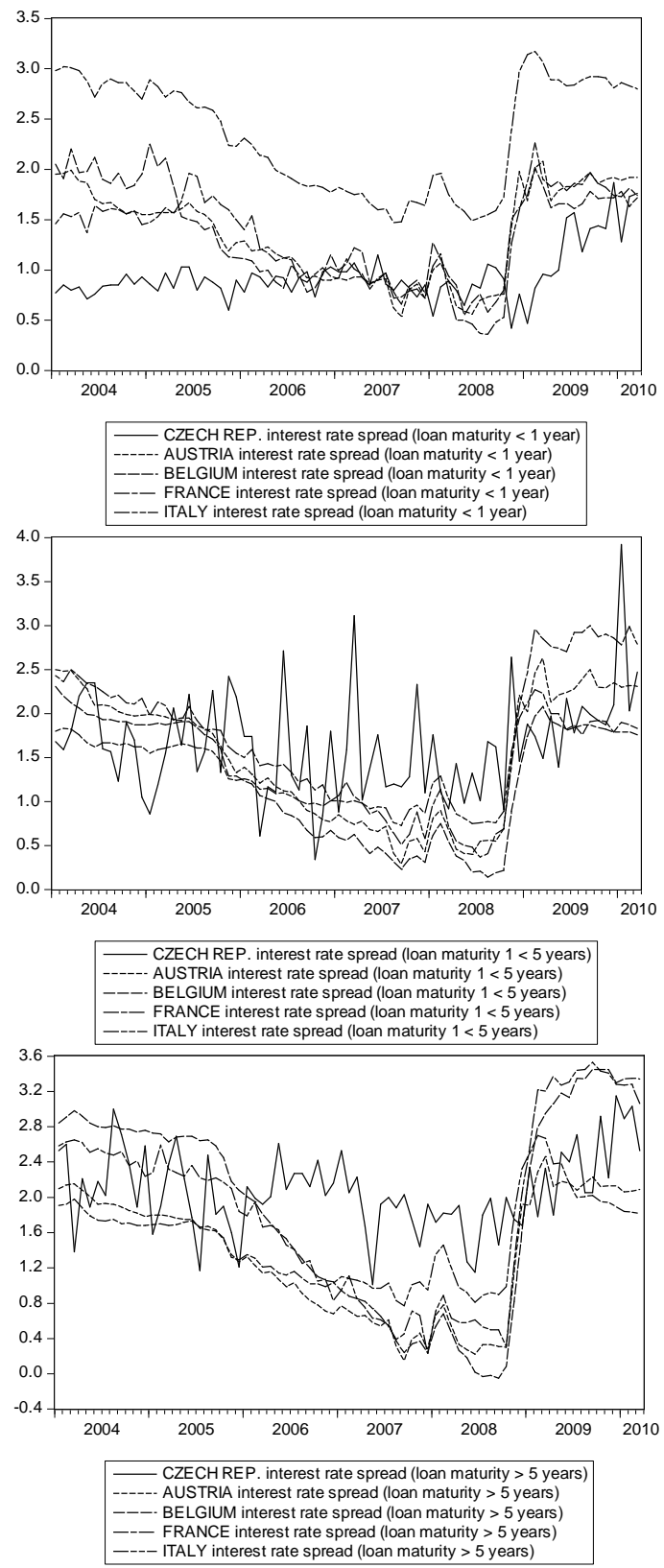


\section{Appendix 3: Correlations between interbank interest rates and bank}

credit margins

\begin{tabular}{|c|c|c|c|c|}
\hline & $\begin{array}{l}\text { EURIBOR } \\
1 \text { month }\end{array}$ & $\begin{array}{c}\text { EURIBOR } \\
3 \text { months }\end{array}$ & $\begin{array}{c}\text { EURIBOR } \\
6 \text { months }\end{array}$ & $\begin{array}{l}\text { EURIBOR } \\
12 \text { months }\end{array}$ \\
\hline $\begin{array}{c}\text { AUSTRIA margin } \\
\text { (loan maturity }<1 \text { year) }\end{array}$ & -0.53 & -0.58 & -0.59 & -0.58 \\
\hline $\begin{array}{c}\text { AUSTRIA margin } \\
\text { (loan maturity } 1<5 \text { years) }\end{array}$ & -0.63 & -0.66 & -0.68 & -0.66 \\
\hline $\begin{array}{c}\text { AUSTRIA margin } \\
\text { (loan maturity }>5 \text { years) }\end{array}$ & -0.74 & -0.77 & -0.77 & -0.74 \\
\hline $\begin{array}{c}\text { BELGIUM margin } \\
\text { (loan maturity }<1 \text { year) }\end{array}$ & -0.43 & -0.45 & -0.46 & -0.44 \\
\hline $\begin{array}{c}\text { BELGIUM margin } \\
\text { (loan maturity } 1<5 \text { years) }\end{array}$ & -0.78 & -0.84 & -0.87 & -0.87 \\
\hline $\begin{array}{c}\text { BELGIUM margin } \\
\text { (loan maturity }>5 \text { years) }\end{array}$ & -0.90 & -0.96 & -0.98 & -0.97 \\
\hline $\begin{array}{c}\text { FRANCE margin } \\
\text { (loan maturity }<1 \text { year) }\end{array}$ & -0.59 & -0.63 & -0.65 & -0.65 \\
\hline $\begin{array}{c}\text { FRANCE margin } \\
\text { (loan maturity } 1<5 \text { years) }\end{array}$ & -0.75 & -0.79 & -0.80 & -0.77 \\
\hline $\begin{array}{c}\text { FRANCE margin } \\
\text { (loan maturity }>5 \text { years) }\end{array}$ & -0.87 & -0.83 & -0.82 & -0.78 \\
\hline $\begin{array}{c}\text { ITALY margin } \\
\text { (loan maturity }<1 \text { year) }\end{array}$ & -0.69 & -0.72 & -0.75 & -0.76 \\
\hline $\begin{array}{c}\text { ITALY margin } \\
\text { (loan maturity } 1<5 \text { years) }\end{array}$ & -0.70 & -0.74 & -0.77 & -0.78 \\
\hline $\begin{array}{c}\text { ITALY margin } \\
\text { (loan maturity > } 5 \text { years) } \\
\end{array}$ & -0.70 & -0.72 & -0.75 & -0.76 \\
\hline $\begin{array}{l}\text { CZECH. REP. margin } \\
\text { (loan maturity }<1 \text { year) }\end{array}$ & 0.18 & 0.07 & 0.07 & 0.07 \\
\hline $\begin{array}{c}\text { CZECH. REP. margin } \\
\text { (loan maturity } 1<5 \text { years) }\end{array}$ & -0.12 & -0.10 & -0.09 & -0.12 \\
\hline $\begin{array}{c}\text { CZECH. REP. margin } \\
\text { (loan maturity > } 5 \text { years) }\end{array}$ & 0.04 & 0.00 & 0.00 & -0.01 \\
\hline & $\begin{array}{l}\text { PRIBOR } \\
1 \text { month }\end{array}$ & $\begin{array}{l}\text { PRIBOR } \\
3 \text { months }\end{array}$ & $\begin{array}{l}\text { PRIBOR } \\
6 \text { months }\end{array}$ & $\begin{array}{l}\text { PRIBOR } \\
12 \text { months }\end{array}$ \\
\hline $\begin{array}{c}\text { CZECH. REP. margin } \\
\text { (loan maturity }<1 \text { year) }\end{array}$ & -0.01 & -0.19 & -0.23 & -0.23 \\
\hline $\begin{array}{c}\text { CZECH. REP. margin } \\
\text { (loan maturity } 1<5 \text { years) }\end{array}$ & -0.17 & -0.10 & -0.08 & -0.09 \\
\hline $\begin{array}{c}\text { CZECH. REP. margin } \\
\text { (loan maturity }>5 \text { years) }\end{array}$ & 0.06 & 0.00 & -0.03 & -0.02 \\
\hline
\end{tabular}




\title{
How Related are Interbank and Lending Interest Rates? Evidence on Selected European Union Countries
}

\author{
Tomáš HERYÁN - Daniel STAVÁREK
}

\begin{abstract}
This paper investigates the nature of the causal relationships among interbank market interest rates and corporate loans interest rates in four countries from the euro area (Austria, Belgium, France and Italy), and in the Czech Republic. The paper also estimates a development of bank credit margin in banking industries of these countries in period from January 2004 to March 2010. Using Johansen cointegration and Granger causality tests on monthly data we investigate long-term as well as short-term causalities between the interest rates. The results suggest that interest rate relationships differ in all selected countries, and also that foreign majority owners of the Czech banks could affect interest rate policy of the subsidiaries to offset losses realized by the parent banks.
\end{abstract}

Key words: Cointegration; Granger Causality; Interbank Interest Rates; Lending Interest Rates; European Union.

JEL classification: C32, E40, E43, E52, F36. 